Matthias Tomczak

Flinders University • Adelaide, Australia

\title{
UNDERGRADUATE OCEANOGRAPHY EDUCATION IN A GLOBAL WORLD
}

My last contribution to the Oceanography Classroom, in which I addressed undergraduate oceanography education in a global world, ended with a promise to discuss graduate oceanography education next. I now hold the September 2003 issue of our magazine in my hands and notice the contribution of Brix et al. (2003) on a similar theme, so these pages can be seen as directing the spotlight on the same topic from a different angle.

One of the issues discussed by Brix and co-authors is the variation in the time allocated to graduate studies. Brix et al. point out that at many universities the duration of Ph.D. degrees is shorter than what we would consider academically adequate. To change that situation requires an understanding of the causes.

One of the first universities of the "Western World", the Museum and Library of Alexandria, was founded before 300 B.C. Staff and students received free board and lodging for the duration of their stay, which was unlimited. In return they were required to engage in scientific discussion with their colleagues and to lend all manuscripts in their possession to the Library for copying. Among the many generations of famous scientists were such illustrious names as Archimedes, Ptolemy and Euclid, who established the foundations of science for the next 1500 years-not a bad return on what was undoubtedly a significant part of Egypt's state budget.

The situation had only changed in minor ways when I studied in Germany in the 1960s. Universities did not provide free board and lodging any more, but courses were still free, and there was no limit on the time students spent at the university.

The first significant change came with the collapse of the colonial empires. Many colonies gained national independence during the 1960s, and the governments of the new independent nations sent their brightest sons and daughters out to obtain science degrees. To cover their living expenses they supported them with scholarships, which came out of meagre state budgets and had to be paid in hard currency. Supporting someone for overseas studies was thus a significant national investment, and the recipient of a government scholarship was under much pressure to perform well. Naturally there was a time limit to any scholarship; the new governments of Africa, Latin America and Asia could not afford to support students for unlimited lengths of study.
My first experience with this new constraint on graduate studies goes back to the 1970s when a student from modern Egypt approached me for help. He was convinced that he could not complete his Ph.D. in the allocated time and was afraid to be sent home without a degree. It soon became clear that such an outcome was more or less a death sentence for him: his country had invested precious resources in his education, which he would have wasted if he returned without his expected degree, and the best he could look forward to was a life in disgrace as a street-sweeper.

As a young post-doctoral fellow I was distressed by the indifference of the student's supervisor. In hindsight it is clear that the constraints under which most foreign students had to study presented new conditions for universities for which most supervisors were ill prepared. The role of the supervisor undergoes a qualitative change when obtaining a degree turns from a desirable outcome into a life-or-death decision.

I spent the next 15 years in research without much contact to educational matters. When I returned to university life in the late 1980s the situation was about to change in a most dramatic way. Governments of the developed world were discovering graduate education as a new way to extract money from their lost colonies. Through a range of legislation measures they forced the universities to charge full fees to foreign students. Governments in Africa, Latin America and Asia now had to support their students not only with living expenses; their scholarships now had to include tens of thousands of hard currency dollars for university fees as well.

The increased cost of training their future scientists forced these countries to drastically limit the duration of scholarships. Three years became the standard length, with an additional six months if it could be shown that a project required the extra time for completion.

As a result, foreign students now studied under conditions radically different from nationals of the host countries, and responsible supervisors had to learn how to make sure that their overseas Ph.D. candidates completed their degrees in time. My recollections from the early 1990s include scenes from the life of a student from Asia, one of my best graduates, who lived the last three weeks of his candidature in his office; during the day his wife cooked for him, during the night she slept with her baby on a mattress on the floor while he frantically put his thesis together. 
Some countries were so short of funds that they sent their best students overseas on two year scholarships to obtain M.Sc. degrees. One of my African students was such a gifted student that he rose to director of the National Institute of Marine Science within two years of his return from university. I pleaded with his government to give him another year's funding and change his status to Ph.D. candidate. I was told that this would deny other gifted students their chance to study overseas and was therefore unacceptable.

The usual solution if a scholarship runs out is, of course, part-time employment from research funding. But study and employment are covered by different visa classes, and it took me another six months of dogged argument with the Australian government before it was prepared to let that student stay and complete his $\mathrm{Ph} . \mathrm{D}$. degree.

This was ten years ago, when students with an Australian passport could still attend university without time restriction. It was the training phase for Ph.D. supervisors; they had to learn how to define Ph.D. research projects that can be completed in three years. Academics who could not think of a way to achieve this could of course decline the supervision of overseas students. It would have given them only temporary reprieve: today the three year limit applies to all graduate students regardless of nationality.

One obvious consequence of an enforced time limit is that certain research activities are no longer acceptable as Ph.D. projects. Oceanography developed as a field science, and field observations will remain the backbone of all oceanographic research. Nothing has changed since 350 B.C. in that respect, when Aristotle wrote: "Credit must be given to observation rather than to theories, and to theories only insofar as they are confirmed by the observed facts." But students of the 21st century are advised not to embark on field observations that may require another year to confirm their findings, because as Ph.D. students they cannot afford to wait for another year. Through the actions of governments Ph.D. studies in oceanography are now restricted to "safe" projects that can be completed in three years without risk.

The step from the three year limit of candidature for overseas students to the same limit for national students brought another qualitative change. Overseas students depend on scholarships, and their presence in the country of study can be controlled through visa regulations. Enforcing time limits on national graduate students requires legislation. While supervision of foreign students created a moral obligation for supervisors to make sure that their students succeed, legislation creates administrative pressure from the university. The Australian model makes this particularly obvious.

Australian universities are funded on student numbers. The total student intake for each university is determined annually, and graduate places are funded for three years. Students who continue graduate studies after their three years are up cause the universities financial harm, not only because their enrollment is no longer funded, but also because they still count as part of the total intake, and university funding is proportionally reduced.

Government bureaucrats will tell you that forcing outcomes through economic micro-management is the safest way to achieve results. The reality is that the "economic guidance" of universities practiced by the Australian government produces serious distortions of academic activity. If Australian universities want to implement the proposal of Brix et al. (2003) and extend Ph.D. enrollment to four years they will have to find substantial additional funds. The methods to achieve this are many, and there is no limit to innovation. To give two examples, it is now possible in Australia to enroll in a three-year degree in surfing. Such a degree costs little to run, attracts full government funding and produces much needed spare cash. Another university offers "Science in the movies", an extremely popular course where students can gain science credits for watching The X-files, with a commentary from the lecturer.

I cannot say to which degree the Australian situation is representative for the situation in Europe or North America; the details may vary, but it would surprise me if the trend is much different. And there is real cause for alarm. It is easy for a government to expose universities to ridicule with degree offerings in surfing, movie watching and other esoteric science topics. Australia's education minister has already used this simple ruse to announce that he is preparing legislative changes that will allow him to reduce a university's funding in proportion to the number of courses that the minister deems "cappuccino courses."

I began this column in Alexandria, where the principle of education as a right for everyone was practiced in 300 B.C. Today this right is enshrined in the Universal Declaration of Human Rights of the United Nations. Another basic principle practiced in Alexandria and still valid today is the autonomy of universities. It is a principle as important and basic as the independence of the judiciary and has been defended again and again through the millennia.

The proposal of Brix et al. (2003) deserves our full support. If we want to turn it into reality we have to make a determined effort and defend the right of universities to set their own academic standards. 다

\section{Reference}

Brix, H., J.L. Hench, H.L. Johnson, T.M.S. Johnson, J.A. Polton, M. Roughan and P. Testor, 2003: An International Perspective on Graduate Education in Physical Oceanography. Oceanography, 16(3), 128-129. 